Creative Commons User License: CC BY-NC-ND

Abstracted by: EBSCOhost, Electronic Journals Service (EJS),

Google Scholar, Journal Seek, Scientific Commons,

Food and Agricultural Organization (FAO), CABI and Scopus
Journal of Agricultural Extension

Vol. 23 (4) October, 2019

ISSN(e): 24086851; ISSN(Print); 1119944X

http://journal.aesonnigeria.org

http://www.ajol.info/index.php/iae

Email: editorinchief@aesonnigeria.org

\title{
Impact of New Seed Varieties Programme on the Welfare of Rice Farmers in Indonesia: A Propensity Score Matching Approach
}

https://dx.doi.org/10.4314/jae.v23i4.16

\section{Achmad Rifa'i}

Faculty of Economics and Business, Universitas Gadjah Mada, Indonesia

Email: achmadrifai186@gmail.com Phone: +62 85769518671

\section{Salman Samir}

Faculty of Economics and Business, Universitas Gadjah Mada, Indonesia

Email: salmansamirmsc@gmail.com Phone: +62 85342740927

\section{Abstract}

The study examined rice farming in Indonesia on the welfare of farmers using Indonesia Family Life Survey (IFLS) 2014 as data source. Propensity Score Matching (PSM) is employed to see further differences in farmer welfare impacts to programme beneficiaries and non-beneficiaries of the new seed varieties programmes. The reveal that the new seed varieties programme is positively and significantly impactful on the welfare of farmers. Thus, innovative programmes in the agricultural sector must continue to be encouraged because of the implications of being able to improve the welfare of farmers. Then at the macro level it will help poverty alleviation programmes in Indonesia

Keywords: New seed varieties programme, welfare of farmers, IFLS, PSM

\section{Introduction}

Agriculture has important and strategic meaning in national development. According to Indonesia Central Bureau of Statistics (BPS) in 2017 revealed that the agricultural sector is the main food supply sector which is a source of livelihood for most of population in Indonesia both for poor households and not with percentage 49.89 and 29.16 respectively. ${ }^{1}$ Therefore, the government as the regulator must pay special attention to development in the agricultural sector, especially in rice. Attention in this sector will also directly provide various fundamental development impacts, especially in terms of food defence and poverty alleviation. However, government programme planning is carried out by various ministries including the Ministry of Agriculture. In making the programme, each ministry must refer to National Medium Term Development Plan (RPJMN).

RPJMN is a five-year planning document made by the government to be used as a reference in implementing development. When the 2010-2014 RPJMN has ended, the government needs to conduct a development evaluation as an effort to improve

\footnotetext{
${ }^{1}$ www.bps.go.id/subject/23/kemiskinan-dan-ketimpangan.html\#subjekViewTab3
} 
Creative Commons User License: CC BY-NC-ND

Abstracted by: EBSCOhost, Electronic Journals Service (EJS), Google Scholar, Journal Seek, Scientific Commons,

Food and Agricultural Organization (FAO), CABI and Scopus
Journal of Agricultural Extension

Vol. 23 (4) October, 2019

ISSN(e): 24086851; ISSN(Print); 1119944X

http://journal.aesonnigeria.org

http://www.ajol.info/index.php/iae

Email: editorinchief@aesonnigeria.org

the development plan which will later be put into RPJMN 2015-2019. Especially in the agricultural sector which is the backbone of Indonesia, it needs to be evaluated related to the success in previous period. Welfare of farmers is the ultimate goal to be achieved from agricultural development. Various policies and activities implemented in building agriculture are a tool or instrument for policy makers in the agricultural sector in an effort to improve the welfare of farmers (Renstra Kementan, 2010-2014). ${ }^{2}$

Welfare of farmers is very important to be discussed, especially in agrarian countries like Indonesia. On the other hand, the government's efforts must also continue to be encouraged to increase national production. Because basically the agricultural sector, especially rice, has a lot of effects on the economy. Simply put, if national production is not fulfilled, the government needs to import, which means it actually makes the selling price of domestic rice as if more expensive. This will cause farmers to suffer losses because the rice is not competitive with imported rice which usually has better quality and more affordable prices. The fall in the price of domestic harvested rice is often the reason why households in the agricultural sector suffer because their income decreases due to the rice they harvest to compete with imported rice. As a result, indirectly the welfare of farmers will decline and in the short term will make the poverty rate increase. Nonetheless, the government is also faced if domestic rice stocks are insufficient while if it is not carried out rice imports will actually further damage the price of rice in the market because it becomes scarce and the price will definitely increase. This actually has a greater scale of loss because households in general will be affected by the scarce and expensive basic necessities even this increase is often accompanied by the high cost of other basic necessities such as chili, onion, and garlic.

However, based on data from BPS in 2014 there was a decline trend in national production and it was also accompanied by a decrease in rice fields (Figure 1). This is certainly a sign that there is a setback from target of RPJMN 2010-2014. ${ }^{3}$ Unfortunately, this decline is not accompanied by the ability of farmers who still use traditional agricultural techniques, especially those in rural areas. In addition, the climate conditions in Indonesia that cannot be predicted sometimes make rice fields damaged. As a result, many fields experienced crop failure. On the other hand, many rice fields in Indonesia have switched to planting such as corn and soybeans when the dry season comes.

\footnotetext{
${ }^{2}$ Renstra Kementan is abbreviation from Strategic Plan of Ministry of Agriculture

${ }^{3}$ www.bumn.go.id/pertani/berita/291/BPS.:.Produksi.Padi.Tahun2014.Diperkirakan.Turun
} 
Creative Commons User License: CC BY-NC-ND

Abstracted by: EBSCOhost, Electronic Journals Service (EJS), Google Scholar, Journal Seek, Scientific Commons,

Food and Agricultural Organization (FAO), CABI and Scopus
Journal of Agricultural Extension

Vol. 23 (4) October, 2019

ISSN(e): 24086851; ISSN(Print); 1119944X

http://journal.aesonnigeria.org

http://www.ajol.info/index.php/iae

Email: editorinchief@aesonnigeria.org

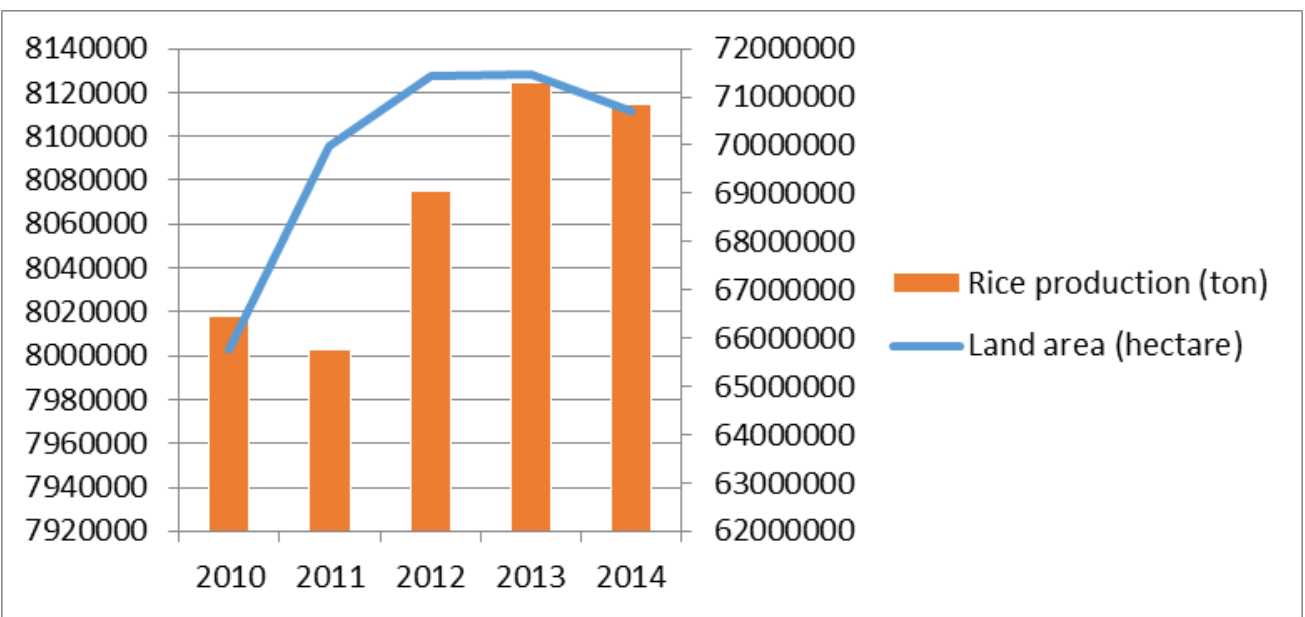

Source: Indonesia Central Bureau of Statistics (BPS)

Figure 1: Rice production and land area

Based on these data, the decline in rice production and land area can be explained through two things. Firstly, external factors such as natural conditions, torrential rains causing floods and volcanoes to erupt and secondly, internal factors such as availability of pesticides, fertilizers, and adequate seeds. Related to seed, this one factor has a crucially important meaning in agribusiness development and food security. New seed varieties play a role not only as one of the important components but also as a determination of the potential of achievable results, the quality of the products to be produced, and the efficiency of production costs.

However, seeds are one of the important components in the agricultural sector such as rice. Adenuga et al (2016) revealed that farmers who adopt improved seeds will have a very broad impact, especially for farmers. Increased rice harvest will indirectly increase the stock of sales materials as well as some of it will be consumed by themselves as basic needs. Furthermore, Shew et al (2019) stated that the use of improved varieties of seed can have an impact not only on farmers but also on the environment, especially the use of more efficient rice fields because harvesting can be done faster when compared to ordinary seeds that have been used so far.

In addition, by keeping rice production stable at least this also contributes to the issue of national food security (Arouna et al., 2017). If every country is able to maintain its food security, the disparity in the food sector will decrease and then bring the world to equality for a decent life. The consequence of a decent life is to alleviate poverty through government policies that touch the community directly.

Thus, it is very important to conduct a comprehensive evaluation regarding the impact of various policies in the agricultural sector, especially rice, which need to be done. Because this will be a material consideration for policy makers to make programmes more effective while tackling poverty. The new varieties seed programme policy can be one of the government's alternatives in increasing rice 
Creative Commons User License: CC BY-NC-ND

Abstracted by: EBSCOhost, Electronic Journals Service (EJS),

Google Scholar, Journal Seek, Scientific Commons,

Food and Agricultural Organization (FAO), CABI and Scopus
Journal of Agricultural Extension

Vol. 23 (4) October, 2019

ISSN(e): 24086851; ISSN(Print); 1119944X

http://journal.aesonnigeria.org

http://www.ajol.info/index.php/iae

Email: editorinchief@aesonnigeria.org

production while making land use more efficient because it can harvest faster than ordinary seeds. In addition, with the increase in rice production it is hoped that it can also increase farmers' income which will affect their welfare.

Building on the results of the aforementioned studies, this research aims to contribute to literature and knowledge to policy makers, especially in the field of rice farming. Seed is one of the factors that is expected to have an important role in increasing the production of farmers in Indonesia which then improve the welfare of farmers as well as contribute in reducing poverty and minimising economic and social disparity.

\section{Methodology}

This study is descriptive with quantitative approach by employing data from IFLS 2014. The use of IFLS 2014 as already mentioned in the introduction is needed to see the impact of new seed varieties programme on welfare of rice farmers in Indonesia. Another thing that motivates the use of IFLS data in 2014 is that based on data form BPS, there is a tendency to decline in rice production in 2014 compared to the previous year. Furthermore, the last published IFLS is in 2014. However, we focus on programme impact evaluation by comparing the farmers who accepted the programme and did not accept the programme during 2014.

In addition, IFLS is a collection of data covering surveys of almost every aspect of household life in Indonesia from individual, household, and community levels. The last round of IFLS surveys was conducted in 24 provinces and panel surveys with high success in recovering respondents up to 90 percent. In this study, the data used covers all levels of surveys related to rice farming in Indonesia. The data used in this study consisted of 17 variables consisting of 1 treatment variables which is new seed varieties programme, 1 outcome variable is net income as a proxy for farmer welfare, and 15 control variables. (Table 1 ). 
Creative Commons User License: CC BY-NC-ND

Abstracted by: EBSCOhost, Electronic Journals Service (EJS),

Google Scholar, Journal Seek, Scientific Commons,

Food and Agricultural Organization (FAO), CABI and Scopus
Journal of Agricultural Extension

Vol. 23 (4) October, 2019

ISSN(e): 24086851; ISSN(Print); 1119944X

http://journal.aesonnigeria.org

http://www.ajol.info/index.php/jae

Email: editorinchief@aesonnigeria.org

Table 1: Identity of variable

\begin{tabular}{ll}
\hline \multicolumn{1}{c}{ Variable } & \\
\hline seed & Dummy 1 if receiving seed programme and 0 for otherwise \\
credit & Dummy 1 if receiving credit programme and 0 for otherwise \\
fertilizer & Dummy 1 if receiving fertilizer programme and 0 for otherwise \\
pesticide & Dummy 1 if receiving pesticide programme and 0 for otherwise \\
Information & Dummy 1 if receiving information programme and 0 for otherwise \\
Education & Number of schooling of head of rice farmer household (Year) \\
Land & Land area (are) \\
Irrigation & Dummy 1 if having irrigation access and 0 for otherwise \\
Rice harvest & Harvest in the form of rice (Kg) \\
Price & Price of rice (Rp/Kg) \\
Household & Number of household members of farmers \\
Frequency of & Frequency of harvest within a year \\
harvest & Dummy 1 if ever failed for harvesting and 0 for otherwise \\
failed for harvesting & Number of plot owned by farmer \\
Plot & Dummy 1 if age of head of rice farmer household $>50$ and 0 for otherwise \\
Age & Dummy 1 if having rice field and 0 for otherwise \\
Rice field & Net income of rice farmer (Rp) \\
Net income &
\end{tabular}

\section{Analytical model}

One of the analytical methods that can be used in research impact evaluation by comparing a group accepting and non-accepting a programme is propensity score matching (PSM). According to that the matching method allows us to substantially reduce the bias but not necessarily eliminate it. Matching method commonly used is PSM. In addition, to enrich literature and comparison of PSM methods with different variables, this study also considers some previous studies to make estimation especially (see Sanchez-Toleda et al., 2018; Asare, 2016; Wilkus et al., 2017; Himire et al., 2015; Xuan \& Bauer, 2016; Jumbe \& Nkhata, 2015; Ahmed \& Mesfin, 2017; and Sahu \& Das, 2015).

The first step in PSM is to analyse the factors affecting the rice farmer household to get a new seed programme using the probit model. The government decided to provide a new seed programme based on household characteristics (geographical, demographic, and socio-economic factors). The probit model can be written as follows:

$$
U_{i}^{*}=X_{i} a+\mu_{i} \text { where }
$$


Creative Commons User License: CC BY-NC-ND

Abstracted by: EBSCOhost, Electronic Journals Service (EJS),

Google Scholar, Journal Seek, Scientific Commons,

Food and Agricultural Organization (FAO), CABI and Scopus
Journal of Agricultural Extension

Vol. 23 (4) October, 2019

ISSN(e): 24086851; ISSN(Print); 1119944X

http://journal.aesonnigeria.org

http://www.ajol.info/index.php/iae

Email: editorinchief@aesonnigeria.org

$U_{i}=\left\{\begin{array}{lll}1 & \text { if } & \begin{array}{l}U_{i}^{3}>0 \\ \text { if otherwise }\end{array}\end{array}\right.$

Where, $U_{i}^{*}$ is new seed programme; a denotes the parameter vector to be estimated; and $\mu_{i}$ is the term error $X_{i}$. Characteristics of household of rice farmers, where $U_{i}=1$, for household of farmers who receive the programme and $U_{i}=0$, for household of rice farmers who do not receive programme.

The second step is comparing the average outcome of rice farmers' households, between those who received new seed varieties programme for rice farm households and those who did not receive new seed varieties programme with average treatment effects on the treated (ATT) method. In the ATT method, some techniques can be done such as; nearest neighbour matching, radius matching, kernel matching, and stratification matching.

The third step is measuring matching quality using recommended standardized bias (SB) and t-test. If the X covariate is randomized to the treatment and control group, the pseudo-R2 value should be low enough. In modelling, it is to measure the impact of outcomes on farm households who receive programme with those who do not receive programme, with estimates of differences as follows.

$\Delta_{i}=Y_{i}^{1}-Y_{i}^{0}$

Where $\Delta_{i}$ is the effect of treatment on individual $i$, where $\mathrm{i}=1,2, \ldots, \mathrm{N}$. and is outcome of farm households who receive programme and do not receive programme. Equation (2) uses cross section data and should calculate the result difference between after and before treatment of each household of rice farmers. However, it is not possible to calculate directly using cross section and calculate the difference between before and after treatment on each household of the same rice farmer. Therefore equation (2) is modified by estimating $\Delta \mathrm{TT}$, as follows.

$$
\Delta_{T T}=E(\Delta \mid D=1)=E\left(Y^{1} \mid D=1\right)-E\left(Y^{0} \mid D=1\right)
$$

(3)

$\Delta_{T T}$ measures the difference between expected outcomes in farm households that can programme and the assumption of outcomes of non-participating farmers.

Equation (3) is used to answer the question (counterfactual), how outcomes that household rice farmers should be able to programme but cannot programme. This is the selection bias of the equation, since $E\left(Y^{0} \mid D=1\right)$ is unobserved in this study. If $E\left(Y^{1} \mid D=1\right)=E\left(Y^{0} \mid D=1\right)$ then the non-programme farm households can be used as a control group. 
Creative Commons User License: CC BY-NC-ND

Abstracted by: EBSCOhost, Electronic Journals Service (EJS),

Google Scholar, Journal Seek, Scientific Commons,

Food and Agricultural Organization (FAO), CABI and Scopus
Journal of Agricultural Extension

Vol. 23 (4) October, 2019

ISSN(e): 24086851; ISSN(Print); 1119944X

http://journal.aesonnigeria.org

http://www.ajol.info/index.php/iae

Email: editorinchief@aesonnigeria.org

This biased observation scenario raises self-selection bias, that is, the household of rice farmers cannot be done as participants at the same time as the recipient of the programme and before receiving the programme. Recommended to use PSM to overcome biased selection here, as it can overcome multi-dimensional problems, arising from the matching procedure of the characteristics of many rice farmers including bias due to unobserved. The bias here can be the difference between the outcome of the household of rice farmers who accept the programme and who do not accept the programme, which can be formulated as follows.

Bias $=E\left(Y^{1} \mid D=1\right)-E\left(Y^{0} \mid D=1\right)$

Equation (4) is capable of capturing the impact of undertakers of treated farmers, then we discard the following non-treated impacts.

$E\left(Y^{0} \mid D=0\right)-E\left(Y^{0} \mid D=1\right)$

The following equation (5) defines some non-participant and non-programme farm households. Therefore, bias is the difference between the impact on participants who can programme and the difference and between the impact on the participants who are not getting the programme and not the participants.

$\Delta_{T T}-E\left(Y^{0} \mid D=0\right)-E\left(Y^{0} \mid D=1\right)=$ $E\left(Y^{1} \mid D=1\right)-E\left(Y^{0} \mid D=1\right)-E\left(Y^{0} \mid D=0\right)+E\left(Y^{0} \mid D=1\right)$

(6)

$\Delta_{T T}-E\left(Y^{0} \mid D=0\right)-E\left(Y^{0} \mid D=1\right)=E\left(Y^{1} \mid D=1\right)-E\left(Y^{0} \mid D=0\right)$

Ideally, bias $=0$ implicating on

$E\left(Y^{1} \mid D=1\right)-E\left(Y^{0} \mid D=0\right)=0 E\left(Y^{1} \mid D=1\right)-E\left(Y^{0} \mid D=0\right)$

(8)

Therefore $\Delta_{T T}$ can overcome the self-selection problem using equation (8).

\section{Results and Discussion}

\section{Propensity Score for Programme Beneficiaries and Non-Beneficiaries}

The probit model was chosen to make estimates using PSM to see the impact of the new seed varieties programme on farmer welfare. When estimating, the value of propensity depends on the covariates included in the probit model. However, there is no clear agreement on the type of covariates that should be included in discrete choice models when estimating the value of propensity. The value of propensity was divided into blocks between groups. The propensity values for the blocks between groups did not differ between programme beneficiaries and non-programme 
Creative Commons User License: CC BY-NC-ND

Abstracted by: EBSCOhost, Electronic Journals Service (EJS), Google Scholar, Journal Seek, Scientific Commons,

Food and Agricultural Organization (FAO), CABI and Scopus

http://eoi.citefactor.org/10.11226/v23i4
Journal of Agricultural Extension

Vol. 23 (4) October, 2019

ISSN(e): 24086851; ISSN(Print); 1119944X

http://journal.aesonnigeria.org

http://www.ajol.info/index.php/iae

Email: editorinchief@aesonnigeria.org

beneficiaries (Table 2), thereby meeting the balanced conditions of the propensity value to be imperative.

Table 2: Propensity score for programme beneficiaries and non-beneficiaries

\begin{tabular}{ccccc}
\hline Seed & Obs & Mean & Min & Max \\
\hline 0 & 220 & 0.57328 & 0.00651 & 0.97336 \\
(Untreated) & & $(0.205807)$ & & \\
1 & 750 & 0.832502 & 0.21357 & 0.99228 \\
(Treated) & & $(0.180198)$ & & \\
& & & & \\
\hline
\end{tabular}

Note: Standard errors in parentheses

\section{Using PSM to Estimate Impact of New Seed Varieties Programme on Farmer Welfare}

Table 3 reveals the estimation of new seed varieties programmes for the control variables used. ${ }^{4}$ Furthermore, from estimate results using probit showed that there are five significant control variables namely fertilizer, pesticide, information, rice far, and size far.

The fertilizer, pesticide, and counselling information shows significant positive results.

\footnotetext{
${ }^{4}$ land_far is dropped due to collinearity
} 
Creative Commons User License: CC BY-NC-ND

Abstracted by: EBSCOhost, Electronic Journals Service (EJS),

Google Scholar, Journal Seek, Scientific Commons,

Food and Agricultural Organization (FAO), CABI and Scopus

http://eoi.citefactor.org/10.11226/v23i4
Journal of Agricultural Extension

Vol. 23 (4) October, 2019

ISSN(e): 24086851; ISSN(Print); 1119944X

http://journal.aesonnigeria.org

http://www.ajol.info/index.php/jae

Email: editorinchief@aesonnigeria.org

Table 3: Propensity score of new seed varieties programme on control variables (probit)

\begin{tabular}{|c|c|c|}
\hline Variable & Coefficient & ME \\
\hline Credit & $\begin{array}{c}0.1568688 \\
(0.1172883)\end{array}$ & 0.03528 \\
\hline Fertilizer & $\begin{array}{c}0.2957225 \\
(0.1205256)\end{array}$ & $0.06650^{* *}$ \\
\hline Pesticide & $\begin{array}{c}0.3465448 \\
(0.1123602)\end{array}$ & $0.07793^{\star *}$ \\
\hline information & $\begin{array}{c}1.192656 \\
(0.1234258)\end{array}$ & 0.26823 \\
\hline educ_far & $\begin{array}{c}0.0034929 \\
(0.0124788)\end{array}$ & 0.00078 \\
\hline sp_far & $\begin{array}{c}0.1272804 \\
(0.0999462)\end{array}$ & 0.02862 \\
\hline irig_far & $\begin{array}{c}0.0276926 \\
(0.1179742)\end{array}$ & 0.00622 \\
\hline rice_far & $\begin{array}{l}-0.0001017 \\
(0.0000436)\end{array}$ & $-0.00002^{* *}$ \\
\hline price_far & $\begin{array}{c}0.000048 \\
(0.0000326)\end{array}$ & 0.00001 \\
\hline size_far & $\begin{array}{c}0.07286 \\
(0.0331227)\end{array}$ & $0.01638^{* *}$ \\
\hline freq_far & $\begin{array}{c}0.0618531 \\
(0.0927797)\end{array}$ & 0.01391 \\
\hline fai_far & $\begin{array}{c}-0.107806 \\
(0.1181254)\end{array}$ & -0.02424 \\
\hline plot_far & $\begin{array}{c}0.0220269 \\
(0.0221635)\end{array}$ & 0.00495 \\
\hline age_far & $\begin{array}{c}0.0402565 \\
(0.1121595)\end{array}$ & 0.00905 \\
\hline
\end{tabular}

Note: Standard errors in parentheses. ME: Marginal Effect. Pseudo $\mathrm{R}^{2}=0.2430$ ${ }^{* *} p<0.05$.

This means that new seed varieties programme will also increase these three variables. These results suggest that opportunities for new seed varieties programme will be greater when fertilizers, pesticides, and extension information 
Creative Commons User License: CC BY-NC-ND

Abstracted by: EBSCOhost, Electronic Journals Service (EJS),

Google Scholar, Journal Seek, Scientific Commons,

Food and Agricultural Organization (FAO), CABI and Scopus
Journal of Agricultural Extension

Vol. 23 (4) October, 2019

ISSN(e): 24086851; ISSN(Print); 1119944X

http://journal.aesonnigeria.org

http://www.ajol.info/index.php/iae

Email: editorinchief@aesonnigeria.org

also increase. The three control variables are basically three of the five other programmes that are also promoted by the government to improve rice yields in Indonesia which will then have implications for increasing welfare of farmers. When these government programmes are in synergy and mutually reinforcing, Indonesian agriculture will be strong and achieve self-sufficiency in the long run.

Another interesting point of this estimation is the positive and significant increase of the probit regression result for the number of household members of the farmer.

Based on empirical results, meaning that the number of family members of farmers will be positively correlated to obtain new seed varieties programme. The argument that is that farm households in Indonesia are in lower middle class. This implicitly implies the knowledge of the head of the household regarding the importance of limiting the number of family members. Many farm households have more than two children in Indonesia. The result of tabulation of size far data shows the highest frequency that is 415 farmer households from 1575 samples that have three children. The tendency to get a new seed support programme for farmers with more family members makes sense because if the government does not provide seed assistance to such farmers, it will hamper the poverty alleviation process in the rice sector.

The rice variable indicates a negative coefficient which means decreasing the harvest in the form of rice will increase the chances of farmers getting bigger seed programme. This is in accordance with the conditions in the field when the harvest decreases meaning there is something wrong during the cultivation process (not including natural disasters such as floods and pest attacks). The indicator of harvest decline can be a powerful reason for the government to provide new seed varieties $s$ for farmers to improve their yields. However, the role of new seeds is vital for producing good quality rice and keeping rice during the cultivation process until it is ready for harvesting. It should be a common concern between the government as a provider of facilities and infrastructure and farmers who are the main actors.

Furthermore, the average treatment effect on the treated (ATT) is used to further examine the impact of seed assistance programmes on the welfare of farmers in Indonesia. The ATT approach used is the nearest neighbour, kernel-based, and stratification matching.(Table 4). 
Creative Commons User License: CC BY-NC-ND

Abstracted by: EBSCOhost, Electronic Journals Service (EJS),

Google Scholar, Journal Seek, Scientific Commons,

Food and Agricultural Organization (FAO), CABI and Scopus

http://eoi.citefactor.org/10.11226/v23i4
Journal of Agricultural Extension

Vol. 23 (4) October, 2019

ISSN(e): 24086851; ISSN(Print); 1119944X

http://journal.aesonnigeria.org

http://www.ajol.info/index.php/iae

Email: editorinchief@aesonnigeria.org

Table 4: Impact of new seed varieties programme on farmer welfare

\begin{tabular}{ccccc} 
Matching & ATT & t-stat & \multicolumn{2}{c}{$\begin{array}{c}\text { Matched } \\
\text { Observations }\end{array}$} \\
\cline { 3 - 5 } & & & Seed & Non-Seed \\
\hline Neighbour & $0.460^{*}$ & 2.069 & 801 & 176 \\
& $(0.222)$ & & & \\
Stratification & $0.350^{*}$ & 2.012 & 801 & 241 \\
& $(0.174)$ & & & \\
Kernel & 0.249 & 1.557 & 801 & 241 \\
& $(0.160)$ & & & \\
\hline
\end{tabular}

Note: Standard errors in parentheses

${ }^{*} p<0.1$

Based on the results of the ATT estimation shows that the new seed varieties programme has impact on the welfare of farmers. These findings are consistent with previous related studies of (Shew et al., 2019). Through three different ATT approaches, it gives different results. However, there is one ATT that is not significant with the kernel approach. Moreover, in contrast, the other two approaches, nearest-neighbor and stratification, show significant t-statistics at the $5 \%$ level. Another thing that supports that new seed varieties programme impact on welfare is through the robustness test (Table 5).

\section{Tabel 5: ATT robustness test}

\begin{tabular}{ccc} 
Coefficient & Std. Error & $P>|z|$ \\
\hline 0.4607324 & 0.2012337 & 0.022
\end{tabular}

ATT robustness test result shows p-value 0.02 which means significant at level $5 \%$. Results confirmed previous ATT testing that new seed varieties programme had an impact of 22.2\% improving farmer welfare (see Table 3-Neighbor). New varietes seed programme also provides an increase in the welfare of farmers by $17.4 \%$ (see table 3-Stratification). New seed varieties programme is widely capable of having a good impact on farmers. Several studies support this statement, such as research (see Shiferaw et al., 2014; Bezu et al., 2014; Mathenge et al., 2014).

The new seed varieties programme should be the government's focus if it wants to make Indonesia self-sufficient in food for the long term. The importance of the seed role must also be supported by many other factors such as irrigation systems, 
Creative Commons User License: CC BY-NC-ND

Abstracted by: EBSCOhost, Electronic Journals Service (EJS), Google Scholar, Journal Seek, Scientific Commons,

Food and Agricultural Organization (FAO), CABI and Scopus
Journal of Agricultural Extension

Vol. 23 (4) October, 2019

ISSN(e): 24086851; ISSN(Print); 1119944X

http://journal.aesonnigeria.org

http://www.ajol.info/index.php/iae

Email: editorinchief@aesonnigeria.org

stability of the price of rice and provision of fertilizer and counselling which will make rice farming in Indonesia strong and able to meet domestic needs. The role of seeds is crucial because it is the base or the beginning of all agricultural flow in Indonesia to create a good and sustainable food system, especially new seed varieties provided by the government. This is important because to make new seeds then it takes a long research and experiment and certainly farmers have no competence, either science or equipment to do so. This is where the role of the government is present to conduct new seed research and then the results are disseminated to the farmers who will conduct farming activities.

\section{Conclusion and Recommendation}

The new seed varieties programme affects on the welfare of farmers positively. Seeds are the main role in the rice farming sector. Improved and good seeds will produce good quality rice. The better the quality of the good rice, the more increase the selling power in the market. This will increase the income of farmers who in turn will gradually improve the welfare of his life for the better.

Attachment to other factors such as weather, agricultural means, and government regulation are closely linked to creating food self-sufficiency in Indonesia. At least, the findings of this research are able to prove that the new seed varieties programme empirically improves farmers' welfare. Through the findings of this research also hopefully the government continues to innovate to create a new seed and can be reached by many farmers in Indonesia so that Indonesia again can be a selfsufficient country in the field of food.

\section{References}

Adenuga, A. H., Omotesho, O. A., Ojehomon, V. E. T., Ayinde, O. E., \& Arouna, A. (2016). Adoption of Improved Rice Varieties and its Impact on Multi-Dimensional Poverty of Rice Farming Households in Nigeria. Applied Tropical Agriculture, 21(1), 24-32.

Ahmed, M. H., \& Mesfin, H. M. (2017). The impact of agricultural cooperatives membership on the wellbeing of smallholder farmers: empirical evidence from eastern Ethiopia. Agricultural and Food Economics.

Arouna, A., Lokossou, J. C., Wopereis, M. C. S., Bruce-oliver, S., \& Roy-macauley, H. (2017). Contribution of improved rice varieties to poverty reduction and food security in sub-Saharan Africa. Global Food Security, 14(August 2016), 54-60.

Asare, R. (2016). Acces to Improved Hybrid Seeds in Ghana: Implication for Establishment and Rehabilitation of Cocoa Farms. Experimental Agriculture, (March), 0-13.

Bezu, S., Kassie, G. T., Shiferaw, B., \& Ricker-Gilbert, J. (2014). Impact of improved maize adoption on welfare of farm households in Malawi: A panel data analysis. World Development, 59, 120-131.

Himire, R. G., Wen-chi, H. U., \& Hrestha, R. B. S. (2015). Factors Affecting Adoption of Improved Rice Varieties among Rural Farm Households in Central Nepal. Rice Science, 22(1), 35-43. 
Creative Commons User License: CC BY-NC-ND

Abstracted by: EBSCOhost, Electronic Journals Service (EJS), Google Scholar, Journal Seek, Scientific Commons,

Food and Agricultural Organization (FAO), CABI and Scopus
Journal of Agricultural Extension

Vol. 23 (4) October, 2019

ISSN(e): 24086851; ISSN(Print); 1119944X

http://journal.aesonnigeria.org

http://www.ajol.info/index.php/iae

Email: editorinchief@aesonnigeria.org

Jumbe, C. B. L., \& Nkhata, R. (2015). Does participation in communal water management improve household income? Evidence from Malawi. Water Resources and Rural Development, 5, 31-46.

Mathenge, M. K., Smale, M., \& Olwande, J. (2014). The impacts of hybrid maize seed on the welfare of farming households in Kenya. Food Policy, 44, 262-271.

Sahu, S. K., \& Das, S. (2015). Impact of Agricultural Related Technology Adoption on Poverty: A Study of Select Households in Rural India. Working Paper 131/2015, (October).

Sanchez-Toledano, B. I., Kallas, Z., Rojas, O. P., \& Gil, J. M. (2018). Determinant Factors of the Adoption of Improved Maize Seeds in Southern Mexico: A Survival Analysis Approach. Sustainability, 10.

Shew, A. M., Durand-morat, A., Putman, B., Nalley, L. L., \& Ghosh, A. (2019). Rice intensification in Bangladesh improves economic and environmental welfare. Environmental Science and Policy, 95(February), 46-57.

Shiferaw, B., Kassie, M., Jaleta, M., \& Yirga, C. (2014). Adoption of improved wheat varieties and impacts on household food security in Ethiopia. Food Policy, 44, 272-284.

Wilkus, E. L., Francesconi, G. N., Jäger, M., Wilkus, E. L., \& Jäger, M. (2017). Rural seed sector development through participatory varietal selection Synergies and trade-offs in seed producers in Western Uganda. Journal of Agribusiness in Developing and Emerging Economics, 7(2), 174-196.

Xuan, D., \& Bauer, S. (2016). Does credit access affect household income homogeneously across different groups of credit recipients? Evidence from rural Vietnam. Journal of Rural Studies, 47, 186-203. 